\title{
Teaching
Methods
}

\section{Lettuce Grow: Universities Collaborating with Nonprofits to Provide Child Care Development Educators with Garden Knowledge and Experience}

\author{
Kathryn Fontenot ${ }^{1,3}$, Edward Bush ${ }^{1}$, and Rebecca Gravois ${ }^{2}$
}

\begin{abstract}
AdDITIONAL INDEX wORDS. daycare, vegetable, survey
SUMMARY. University-based horticulture departments and extension agents have explored the relationship between gardening programs and consumer knowledge and preferences. Studies have established positive correlations between garden participation and increased science scores and heightened environmental stewardship. The objective of this research was to determine if participation in "Lettuce Grow" garden workshops cohosted by the Louisiana State University Agriculture Center (LSU AgCenter) and Volunteers of America Greater Baton Rouge (VOAGBR) had positive effects on child care providers' garden knowledge and willingness to implement garden programming with children aged 5 years and younger. Participation led to a $67 \%$ increase $(P \leq 0.05)$ in horticulture knowledge for participants and resulted in $76.2 \%$ of the child care providers actively engaged in growing a garden with youth aged 5 years and under. Based on this experience, we highly recommend universities partner with local nonprofits to engage in deeper meaning, science-based garden extension projects.
\end{abstract}

$\mathrm{P}$ ublic university systems across the United States face financial difficulties as they are often state funded. Several colleges and universities received up to $20 \%$ budget cuts in 2009 (Doyle and Delaney, 2009). Mitchell et al. (2014) noted that individual states cut university budgets after the 2007-09 recessions leading to a $23 \%$ average reduction in state spending per student. In

\footnotetext{
${ }^{1}$ School of Plant, Environmental and Soil Sciences, Louisiana State University Agriculture Center, 163 Julian C Miller Hall, Baton Rouge, LA 70803

${ }^{2}$ Agriculture and Extension Education and Evaluation, Louisiana State University Agriculture Center, 159 Julian C Miller Hall, Baton Rouge, LA 70803

${ }^{3}$ Corresponding author. E-mail: kkfontenot@ agcenter.lsu.edu.
}

doi: 10.21273/HORTTECH03778-17 addition, several university systems eliminated full time employee (FTE) positions altogether or rehired FTEs as part time employees; 540,2100 , 493,261 , and 1210 FTEs have been lost at the following university systems, respectively: the Pennsylvania State System of Higher Education Arizona University System, the University of North Carolina at Chapel Hill, the University of Florida, and Louisiana State University. Legislators often single out higher education because universities charge tuition and are not among the neediest population entities receiving state funding (Hovey, 1999). From an outsider's perspective, increases in tuition should offset costs associated with salaries, supplies, and building needs of a university. However, universities serve more than just enrolled students. Universities provide educational opportunities and conduct research for the public. This type of work is referred to as extension, service, or outreach. Extension work can be costly. In the horticulture sector, universities reach beyond students to fruit and vegetable producers, the landscape industry, private entities such as arboretums and botanical gardens, the turf industry, hobby gardeners, elementary through high school educators and students, and consumers of all horticulture crops. Urban horticulture, public gardening, and the Farm to Fork movement have increased in popularity, thus increasing demand for extension programs. Many university-based horticulture departments explore the relationship between gardening programs and consumer knowledge and preferences. University-based programs in Louisiana and Texas (Karsh et al., 2009; Klemmer et al., 2005; Smith and Motsenbocker, 2005) studied student knowledge, environmental stewardship and confidence in science-based skills. These studies found positive correlations between garden participation and increased science scores and heightened environmental stewardship. Robinson and Zajicek (2005) assessed changes in life skill development of elementary school students who participated in garden programming. Program participants increased life skill scores by 1.5 points (based on a five-point Likert-type scale) indicating students may become responsible, productive citizens as they age. Other youth-based garden studies focus on nutritional benefits. Faber et al. (2002) evaluated retinol concentrations in children $2-5$ years of age. Children who participated in a home garden program and consumed yellow and dark green leafy vegetables had significantly higher vitamin A levels than those children who did not participate. Collaboration between a university and several nonprofits formed a Growing Healthy Kids program that taught youth to garden and cook. Castro et al. (2013) found $17 \%$ of children with an overweight or obese body mass index (BMI) had improved BMI classification by the end of the program. Additional studies focused on teacher perspectives of school 
garden programs. Skelly and Bradley (2000) provided a questionnaire to evaluate time teachers spent in the school garden and type of lessons given in the garden. The study also evaluated years of garden experience and types of funds teachers had for the garden and found that most teachers used the garden less than $10 \%$ of total instructional time and during that time, environmental-related education was taught. Most respondents had less than 6 months of garden experience, and although most received grants or paid for the garden programming themselves, they felt as though they did not have a good grasp on how to connect the garden to their curriculum. DeMarco (1997) completed a dissertation study evaluating factors affecting integration of a garden into elementary school curriculum. Teachers feel the biggest factors for school garden success are having a responsible person, a garden site, and adequate funding. Within the same survey, teachers indicated that they relied heavily on their own garden knowledge to grow the garden. Teachers expressed a need for education and information on integrating the garden into the curriculum and basic horticulture aspects of growing a garden. They wished this education could be provided as in-service training or continuing education classes in some format, such as graduate school, Master Gardener training etc. There is still much to explore regarding the relationship between youth and garden programs. Researching the two requires time, money, and established relationships between those creating garden programing and those receiving it. The objective of this research was to determine if participation in "Lettuce Grow" garden workshops cohosted by the LSU AgCenter and VOA-GBR would have positive effects on child care providers' garden knowledge and willingness to implement garden programming with children aged 5 years and younger.

\section{Materials and methods}

Collaboration OF A NONPROFIT AGENCY WITH A UNIVERSITY. VOAGBR has a continuing education program for child care providers of youth ages infant through 5 years of age. The staff of VOA-GBR are trained in child development, education and curriculum development for this age group. VOA-GBR personnel received a grant to supply child care providers with materials to construct gardens at child care development centers and at the homes of in-home child care providers. Because the nature of the grant was horticulture based, VOAGBR collaborated with the LSU AgCenter faculty to deliver programming related to planting and maintaining a vegetable garden. The two entities, VOA-GBR and the LSU AgCenter collaborated 3 years (2013$15)$ to conduct full day workshops for child care providers.

WORKSHOP AGENDA To increase participation, all workshops were hosted on Saturdays as that is the most convenient time for child care providers. Workshops began at 8:30 AM and ended at 3:00 PM. Registration, welcome, and a preworkshop survey were completed between 8:30 and 9:00 AM. From 9:00 to 9:45 AM, VOA-GBR faculty addressed connecting gardening to the Birth to Five Early Learning and Development Standards [ELDS (Louisiana Department of Education, 2013)] used to direct child care providers in developing their daily curriculum. A break was provided between 9:45 and 10:00 AM. LSU AgCenter faculty discussed the basics of building a raised bed garden, properly amending soils, planting schedules for vegetable and herb crops, and general garden maintenance. The presentation focused on basic horticulture principles such as appropriate planting dates, proper pruning, trellising and harvest methods of vegetable crops, fertilizing, irrigation, and pest control. This discussion was provided in the form of a PowerPoint (Microsoft, Redmond, WA) presentation and took place between 10:00 and 11:30 AM. The indoor garden presentation was immediately followed by a tour of the children's garden located at the Burden Botanical Gardens in Baton Rouge, LA. Child care providers planted seeds and transplants into the children's garden, learned basic staking methods for crops such as tomato (Solanum lycopersicum) and pepper (Capsicum annuum), and seeded trays of vegetable crops for use at individual centers. A working lunch was provided at noon to allow child care providers time to work on planting calendars for individual child care centers. From noon to $12: 30 \mathrm{PM}$, teachers received their individual garden supplies and explanations on how to use the given supplies. Each child care center and in-home child care provider was provided: one $4 \times 4$-ft $(1.2 \mathrm{~m})$. planter box, two watering cans, various packages of vegetable and herb seeds for spring and fall gardens, child-sized tools including, trowels, hoes, shovels, and rakes (three of each), two trays (72 vegetable seedlings) teachers planted at the workshop, a copy of Flower Garden (Bunting and Hewitt, 2000), copies of LSU AgCenter school garden publications including one copy of Steps to Growing a Successful Garden (Fontenot et al., 2010), one copy of A Guide to Controlling Insects in the School Garden (Fontenot et al., 2013), and one copy of Food Safety in Louisiana School Gardens (Fontenot et al., 2014).

At 1:00 PM, VOA-GBR led discussions and had child care providers work in groups to develop ideas for garden-themed learning centers, themed units, and lesson plans. Garden lessons were developed around existing curriculum. For example, if rhythm and rhyme were a unit, the child care provider groups changed words of common nursery rhymes such as "Row Row Row Your Boat" to garden themed phrases such as "Dig Dig Dig Your Soil.” Early childhood curriculum used in the Louisiana's Birth to Five ELDS focus on colors, shapes, numbers (1-10) letters of the alphabet, plants, weather, and other basic concepts (Louisiana Department of Education, 2013). Child care provider groups also discussed using the garden to teach letters and numbers of the day. For instance, "S" day would be shovel day and "T" day would be tomato day. Teachers were permitted to work in groups and make final presentations of units, lessons, and centers from 12:30 to 2:30 PM. After which, child care providers submitted a short, curriculum action plan stating three activities they pledged to incorporate around the garden in their classroom. The teachers took the post garden workshop survey at the conclusion of the workshop at 3:00 PM.

PRE - AND POSTWORKSHOP SURVEYs. To assess prior knowledge and knowledge gained from the workshop, each child care provider completed a pre- and postworkshop 
survey. Questions on the survey simply addressed the child care provider's horticulture knowledge not their ability to integrate the garden into a curriculum (Table l). Questions were awarded one point for the correct answer and zero points for an incorrect answer. One point was given if a respondent answered correctly when asked which vegetables were planted in fall and spring. Data were statistically analyzed using a paired samples $t$ test (IBM SPSS Statistics version 23.0; IBM Corp., Armonk, NY). Answers to all survey questions were addressed throughout the workshop. Child care providers were not allowed to use their handouts or each other when completing the pre- or postworkshop survey.

FOLLOW-UP ACTION PLANS. VOA-GBR not only provided the child care providers with tools to begin the garden; they also gave each participant $5 \mathrm{~h}$ of training. Training hours are required to maintain active child care center licenses in the state of Louisiana. If teachers received the supplies, built the gardens, and provided evidence of using the gardens with children within 3 months of the workshop, they were provided with an additional certificate for $3 \mathrm{~h}$ of training. Over the 3 years (2013-15), this program was able to provide information and supplies to 105 child care providers representing 56 child care centers. About 3 months after each workshop, VOA-GBR staff visited each child care center and in-home child care provider to determine if the garden was built, planted, and actively used with children.

\section{Results}

Child care providers scored an average of $18.5 \%$ on the preworkshop survey and $85.5 \%$ on the postworkshop survey. There was a $67 \%$ change in mean score just by attending one garden workshop in horticulture knowledge for these educators. Scores on each individual test question increased by a minimum of $37 \%$ points (Table 1 ). Whereas most school garden studies focus on student attitude and knowledge (Karsh et al., 2009; Klemmer et al., 2005; Robinson and Zajicek, 2005; Smith and Motsenbocker, 2005) and show positive correlation with gardens and student's knowledge and perceptive of the environment and vegetables and fruit, very few studies actually study changes in teacher or school garden volunteer knowledge as a result of the programming. However, our study did address one request made by school garden educators in the DeMarco (1997) study, to provide additional basic horticulture information as an in-service training. Our results not only indicate positive changes in child care provider knowledge but also actual use of the garden with students. Of the 105 child care providers that attended this workshop, 80 actively constructed the garden and, to date of this publication, continue to actively use curriculum and garden with children. Eight of the child care providers neither built the garden nor did they use any of the garden curriculums in their classes. Seventeen child care providers had planted the garden within 3 months of participation in the workshop but, to date, are no longer employed at the same child care center or the child care center has closed. The addition of the workshop before giving the child care providers garden supplies may have been an influential proponent in the child care centers building and engaging with students in the garden. Skelly and Bradley (2000) indicated that teachers

used the garden less than $10 \%$ of instructional time, and DeMarco (1997) indicated that teachers felt the need for more instruction before participation in a garden program. Had the teachers in Skelly and Bradley's (2000) study received additional training, they may have used the gardens more than $10 \%$ of time. Although we did not ask the frequency or average time spent in the garden, we did find a positive correlation with providing garden training and actual use of the garden. The "Lettuce Grow" workshop was an effective means to create sustainable gardens, as $76.2 \%$ of participants actively engaged in growing a garden and used garden curriculum with students ( $\mathrm{Ta}-$ ble 2).

\section{Discussion}

Universities across the United States are facing funding problems (Doyle and Delaney, 2009). Collaborating with local entities such as nonprofits is imperative to continue garden programming that is science based, reaches a wide range of clientele, and is economically feasible for both the provider and person receiving the training. In the case of the "Lettuce Grow" workshop cohosted by the LSU AgCenter and VOA-GBR, 105 participants

Table 1. Child care provider responses on the pre- and postworkshop test given at the Louisiana State University Agriculture Center and Volunteers of America Greater Baton Rouge 2013-15 “Lettuce Grow" workshops $(N=105)$.

\begin{tabular}{lcccrrrrr}
\hline & Q1 $^{\mathrm{z}}$ & Q2 & Q3 & Q4 & Q5 & Q6 & Q7 & Avg score \\
\cline { 2 - 8 } Test period & \multicolumn{7}{c}{$\mathbf{( \% )}$} \\
Pretest & $20^{\mathrm{y}}$ & 42.9 & 14.3 & 9.5 & 3.8 & 11.4 & 53.3 & 18.5 \\
Posttest & 80 & 83.8 & 65.7 & 92.4 & 87.6 & 91.4 & 90.5 & 85.5 \\
\hline
\end{tabular}

${ }^{2}$ Question $\mathrm{l}(\mathrm{Q} 1)=$ Can you name three vegetables grown in the FALL? $\mathrm{Q} 2$ = Can you name three vegetables grown in the SPRING? Q3 = How deep should a raised bed or container be for ideal root growth?

inches. Q4 = How many inches of water should most vegetables receive each week? is a complete fertilizer? Q6 = What should you do if your school garden becomes infested with insects or disease? $\mathrm{Q} 7$ = After this training, whom should you call if you have specific garden questions?

${ }^{\mathrm{y}}$ Numbers within columns are significant at $P \leq 0.05$. Data in columns represents the valid percent of respondents answering the question correctly. For Q1 and Q2, all three vegetables had to be correctly identified to receive credit.

Table 2. Participants actively engaged in growing gardens and using garden curriculum as a result of participation in the 2013-15 Louisiana State University Agriculture Center and Volunteers of America Greater Baton Rouge "Lettuce Grow" workshops.

\begin{tabular}{lcr}
\hline & \multicolumn{2}{c}{ Participants } \\
\cline { 2 - 3 } Participant answer & (no.) & (\%) \\
\hline No & 8 & 7.6 \\
Yes & 17 & 16.2 \\
No longer employed or & & \\
$\quad$ child care center not open in 2016 & 105 & 100 \\
Total & &
\end{tabular}


received science-based garden information to incorporate a garden into their current child care curriculum. VOAGBR staff had previously built relationships with child care providers throughout Baton Rouge and surrounding areas. They also received funding to help train child care providers in garden curriculum but needed expertise in gardening and, thus, partnered with the LSU AgCenter. This cooperation led to a $67 \%$ increase $(P \leq 0.05)$ in horticulture knowledge for participants and resulted in $76.2 \%$ of the child care providers actively engaged in growing a garden with youth aged 5 years and under. Based on this experience, we highly recommend universities partner with local nonprofits to engage in deeper meaning, science-based garden extension projects. This partnership is the first of many that will explore methods to increase garden knowledge and participation of those working with youth.

\section{Literature cited}

Bunting, E. and K. Hewitt. 2000. Flower garden. lst ed. Houghton Mifflin Harcourt, Boston, MA.

Castro, D.C., M. Samuels, and A.E. Harman. 2013. Growing healthy kids. A community garden-based obesity prevention program. Amer. J. Prev. Med. 44: S193-S199.
DeMarco, L.W. 1997. The factors affecting elementary school teachers' integration of school gardening into the curriculum. PhD Diss., Virginia Polytech. Inst. State Univ., Blacksburg.

Doyle, W.R. and J.A. Delaney. 2009. Higher education funding: The new normal. Change Mag. 41(4):60-62.

Faber, M., M.A. Phungula, S.L. Venter, M.A. Dhansay, and A.S. Benadé. 2002. Home gardens focusing on the production of yellow and dark-green leafy vegetables increase the serum retinol concentrations of 2-5-y-old children in South Africa. Amer. J. Clin. Nutr. 76:1048-1054.

Fontenot, K., G. Henderson, and A. Morgan. 2013. A guide to controlling insects in the school garden. Louisiana State Univ. AgCenter Publ. 3303.

Fontenot, K., J. Boudreaux, D. Gill, and A. Blanchard. 2010. Steps to growing a successful school garden. Louisiana State Univ. AgCenter Publ. 3145.

Fontenot, K., A. Adhikari, E. Bush, R. Williams, and F. Malekian. 2014. Food safety in Louisiana school gardens. Louisiana State Univ. AgCenter Publ. 3356.

Hovey, H.A. 1999. State spending for higher education in the next decade: The battle to sustain current support. Natl. Ctr. Public Policy Higher Educ. NCR99-3k.

Karsh, K., E. Bush, J. Hinson, and P. Blanchard. 2009. Integrating horticulture biology and environmental coastal issues into the middle school science curriculum. HortTechnology 19:813-817.

Klemmer, C.D., T.M. Waliczek, and J.M. Zajicek. 2005. Growing minds: The effect of a school gardening program on the science achievement of elementary students. HortTechnology 15:448-452.

Louisiana Department of Education. 2013. Louisiana's birth to five early learning and development standards. 10 Oct. 2016. <http://www.louisianabelieves. com/docs/academic-standards/earlychildhood-birth-to-five-standards.pdf>.

Mitchell, M., V. Palacios, and M. Leachman. 2014. States are still funding higher education below pre-recession levels. 25 June 2017. <http://www.cbpp.org/research/ states-are-still-funding-higher-educationbelow-pre-recession-levels $>$.

Skelly, S.M. and J.C. Bradley. 2000. The importance of school gardens as perceived by Florida elementary school teachers. HortTechnology 10:229-231.

Smith, L.L. and C.E. Motsenbocker. 2005. Impact of hands-on science through school gardening in Louisiana public elementary schools. Hort Technology 15:439443.

Robinson, C.W. and J.M. Zajicek. 2005. Growing minds: The effects of a one-year school garden program on six constructs of life skills of elementary school children. HortTechnology 15:453-457. 